International Journal of Biological Sciences

ISSN 1449-2288 www.biolsci.org 2006 2(2):87-92

Research paper

C2006 Ivyspring International Publisher. All rights reserved

\title{
Free amino acids in the nervous system of the amphioxus Branchiostoma lanceolatum. A comparative study
}

\author{
Juan Pascual-Anaya and Salvatore D'Aniello
}

Departament de Genètica, Facultat de Biologia, Universitat de Barcelona, 08028 Barcelona, Spain

Corresponding address: Salvatore D’Aniello, Departament de Genètica, Facultat de Biologia, Universitat de Barcelona. Av. Diagonal 645 08028, Barcelona, Spain. Tel.: +34 934034795; Fax: +34 934034420; E-mail: salvatoredaniello@ub.edu

Received: 2006.01.15; Accepted: 2006.03.02; Published: 2006.04.10

The cephalochordate amphioxus is the closest invertebrate relative to vertebrates. In this study, using HPLC technique, free L-amino acids (L-AAs) and D-aspartic acid (D-Asp) have been detected in the nervous system of the amphioxus Branchiostoma lanceolatum. Among other amino acids glutamate, aspartate, glycine, alanine and serine are the amino acids found at the greatest concentrations. As it occurs in the nervous system of other animal phyla, glutamate (L-Glu) and aspartate (L-Asp) are present at very high concentrations in the amphioxus nervous system compared to other amino acids, whereas the concentration of taurine and $\gamma$-aminobutyric acid (GABA) is very low. Interestingly, as it is the case in vertebrates, D-aspartic acid is present as an endogenous compound in amphioxus nervous tissues. The physiological function of excitatory amino acids, and D-aspartate in particular, are discussed in terms of evolution of the nervous system under an Evo-fun (Evolution of function) perspective.

Key words: Amphioxus, amino acids, GABA, nervous system, chordates, evolution.

\section{Introduction}

The cephalochordate amphioxus is the closest invertebrate relative to vertebrates. It represents a key animal model, with vertebrate-like characteristics as a dorsal nerve cord, a notochord, segmental muscles, pharyngeal gill slits and a post-anal tail, but it is by far less complex than vertebrates. The genetic programs patterning the amphioxus embryo are also similar to those of vertebrates' embryo, although its genome did not undergo to extensive gene duplication events that characterize vertebrates' genomes. This gives to researchers the opportunity to look at highly conserved embryonic pathways, supported by much simpler genetic information.

Amphioxus was at first thought to be a mollusc by the German zoologist Peter Simon Pallas in 1774 [1], until 1834 when the Italian naturalist Gabriel Costa first described its similarity to vertebrates [2], reconsidering it as a primitive chordate and naming it Branchiostoma lubricum. Two years later, in 1836, William Yarrell named it amphioxus (Amphioxus lanceolatus) and described its notochord [3]. Much later, for its peculiar composition of muscle cells, the amphioxus notochord was defined as an example of evolutionary novelty [4]. They exists at least 28 different species of the genus Branchiostoma described and distributed over the world, but three of them are the mainly studied: the European $B$. lanceolatum, the Floridian-Caribbean B. floridae and the East Asian B. belcheri.

Amphioxus has been successfully used for developmental studies even if it is not easy to obtain embryos in laboratory conditions, due to the unpredictable nature of spawning events. Presently, a full sequencing genome project of the specie $B$. floridae is nearly to be completed at the Joint Genome Institute (US Department of Energy), witch will open the door to a new era for the amphioxus community researchers, and it will strongly enhance comparative studies with other vertebrates and invertebrates animal models.

Although many studies have been conducted on amphioxus, most of them related to morphological and bio-molecular analyses to elucidate developmental-gene pathways, as far we know investigations concerning the determination of free amino acids have not been carried out in this "emerging" animal model. Concentrations of free amino acids in animal tissues, particularly in the nervous system, are of great significance from a biochemical and physiological point of view. Indeed, one of the principal roles of free amino acids is to act as substrates for key enzymatic reaction as well as to regulate the balance of nitrogen compounds.

Moreover, alterations in the concentration of some amino acids lead to important metabolic disorders. For examples, in humans high concentrations of cystine in the urine indicate cystinuria, a congenital defect in the amino acid transport system, which controls the transit of small molecular mass substances in and out of cells across their membranes, ultimately resulting in cystine precipitation in the renal pelvis, forming cystine stones (calculi). An excess of phenylalanine in the blood can cause an illness called "phenylketonuria", a 
mental retardation characterized by the absence of Lphenylalanine hydroxylase, which transforms Lphenylalanine into tyrosine. High levels of tyrosine in the blood are a symptom of the tyrosinosis, a disease characterized by hepatic cirrhosis and renal damage. Nevertheless, mental retardation can result from high concentration of any of the following amino acids: glycine, valine, lysine, glycine, homocystine and hydroxiproline [5].

In addition, some amino acids are involved in neurotransmission; for example, L-Glu and L-Asp are known to be important neurotransmitters, whereas glycine and GABA as neuroinhibitors [6]. Another amino acid, namely D-aspartic acid (D-Asp), has been recently found to be involved in neurotransmission. Evidence has been obtained demonstrating that DAsp plays an important role in hormones release from the neuroendocrine system [7] and acts as a novel neurotransmitter [6]. D-Asp is present at high concentration in the nervous tissues of opistobranchia [8], molluscs, tunicates, crustaceans, amphibians, reptiles, fishes, birds and mammals [9]. In addition, D-Asp has also been detected as a nuclear component of cells in the mammalian hypothalamusneurohypophyseal system [10] and in the retina of Sepia officinalis, where it is implicated in vision [9]. Therefore, in the present preliminary study, in addition to determining the concentration of free Lamino acids in the neural tube of amphioxus, we determined the concentration of D-Asp in order to try to elucidate whether this amino acid could also be involved in neurotransmission.

\section{Material and methods}

\section{Animal collection and tissue homogenisation}

Adult amphioxus (Branchiostoma lanceolatum, the "European specie") were collected in the bay of Argelès-sur-Mer (southern coast of France), at a depth of approximately $10 \mathrm{mt}$ between October and November 2005. Animals were kept for a week in tanks in the laboratory before dissection, at a water temperature of $15^{\circ} \mathrm{C}$ and a 10/14 day-night light cycle. Filtered seawater was changed daily and antibiotics (Streptomycin $100 \mathrm{mg} / \mathrm{L}$ and Penicillin 10 $\mathrm{mg} / \mathrm{L}$ ) were provided to prevent bacteria contamination. Specimens were dissected under a stereoscopic microscope using a micro-fine knife with a $4 \mathrm{~mm}$ cutting edge (F.S.T.), on ice. No anaesthetic was used to immobilize the animals, in order to not alter HPLC measurements. Neural tubes (Fig. 1) from 60 adult animals were collected and divided into 6 groups. Each group, containing a pool of 10 neural tubes weighting about $3 \mathrm{mg}$ total (approximately 0.3 $\mathrm{mg}$ each), was homogenized in $0.1 \mathrm{M}$ TCA (trichloroacetic acid) at a ratio of 1:20, and centrifuged at $15,000 \mathrm{~g}$ for 15 minutes.

Figure 1. Draft of the anterior part of an adult amphioxus (A) (adapted from R. Fox) and the correspondent real picture (B). $\mathrm{C}$ corresponds to the amplification of the red square in B. Acronyms: $\mathrm{nc}$, notochord; nt, neural tube. Scale bar in $\mathrm{B}=1 \mathrm{~mm}$; in $\mathrm{C}=250 \mu \mathrm{m}$

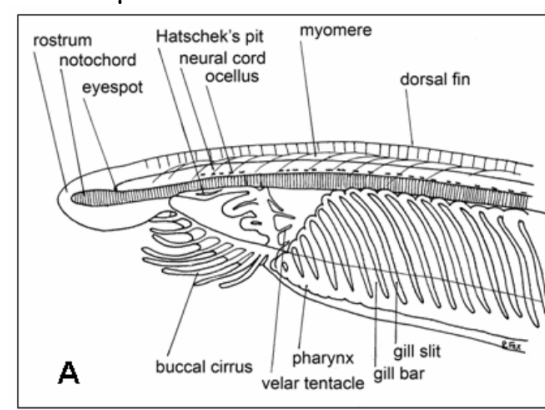

HPLC analysis of D-Asp and L-amino acids

$20 \mu \mathrm{l}$ of the TCA supernatant obtained from homogenisation of each pool of neural tubes was neutralized with $20 \mu \mathrm{l}$ of $0.1 \mathrm{M} \mathrm{NaOH}$ and mixed with $100 \mu \mathrm{l}$ of $0.5 \mathrm{M}$ pyrophosphate buffer $(\mathrm{pH} 9.5)$ and 20 $\mu 1$ of OPA-NAC reagent, which was obtained by mixing $20 \mathrm{mg}$ OPA (o-phthaldialdehyde) with $10 \mathrm{mg}$ NAC (N-acetyl-L-cysteine) in $2.0 \mathrm{ml}$ of methanol. After $2 \mathrm{~min}$, distilled water was added for a final volume of $1.0 \mathrm{ml}$, and $100 \mu \mathrm{l}$ of this mixture was injected into a Supelcosil C-18 HPLC column (0.45 x $25 \mathrm{~cm}$ in length and $5 \mu \mathrm{m}$ beads; Supelco, Bellefonte, PA, USA). Amino acids were eluted using two buffers: A (5\% acetonitrile in $30 \mathrm{mM}$ citrate phosphate buffer, $\mathrm{pH} 5.6)$ and B $(90 \%$ acetonitrile in doubledistilled water), using the following gradient: 0 to $5 \%$ B over 15 min, 5-35\% B over 25 min, 30-100\% B over 5

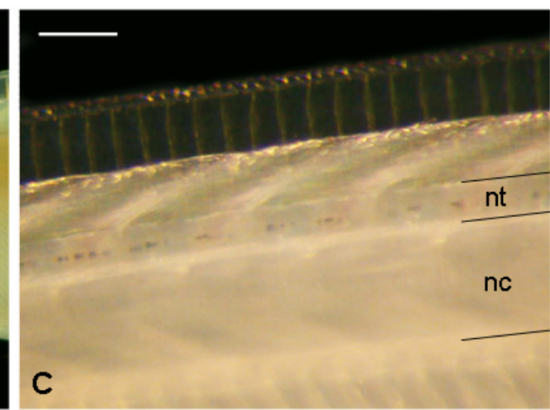

min, staying at $100 \% \mathrm{~B}$ for $3 \mathrm{~min}$, and then returning to $100 \%$ A for $1 \mathrm{~min}$. The flow rate was $1.2 \mathrm{ml} / \mathrm{min}$. Amino acids were detected fluorometrically at an excitation wavelength of $325 \mathrm{~nm}$ and an emission wavelength of $415 \mathrm{~nm}$. D-Asp eluates with a peak at $6.4 \mathrm{~min}$, followed by L-Asp 0.7-0.8 min later and remaining well separated from other amino acids (Fig. $2 \mathrm{a}, 2 \mathrm{~b})$. In order to confirm that the peak eluting at 6.5 min was D-Asp, $20 \mu \mathrm{l}$ of the TCA supernatant was neutralized with $20 \mu \mathrm{l}$ of $0.1 \mathrm{M} \mathrm{NaOH}$ and mixed with $100 \mu \mathrm{l}$ of $0.5 \mathrm{M}$ pyrophosphate buffer ( $\mathrm{pH}$ 8.2) and 2.0 $\mu \mathrm{l}$ of bovine D-Aspartate Oxidase were added to the reaction (D-AspO, $1-2 \mathrm{mg} / \mathrm{ml}$ produced by overexpression in E. coli) [7] and incubated at $37^{\circ} \mathrm{C}$ for 20 $30 \mathrm{~min}$.

Subsequently, $200 \mu \mathrm{l}$ of $0.1 \quad \mathrm{M}$ sodium pyrophosphate $(\mathrm{pH} 10.0)$ was added and the HPLC analysis was repeated as above. The near complete 
reduction of the peak at $6.4 \mathrm{~min}$ confirmed the presence of D-Asp (data not shown). In order to know the exact concentration of D-Asp and L-amino acids, a standard curve was made with known amounts of amino acids purchased from Sigma Chemical Co (St. Louis, Mo) as follows: $10 \mu \mathrm{l}$ of a mixture of 19 different L-amino acids, each at a concentration of 0.1 $\mu \mathrm{mol} / \mathrm{ml}$, and D-Asp at a concentration of 0.01 $\mu \mathrm{mol} / \mathrm{ml}$ that was mixed with $100 \mu \mathrm{l}$ of $0.5 \mathrm{M}$ pyrophosphate buffer $(\mathrm{pH} 9.5)$ and $20 \mu \mathrm{l}$ of OPANAC. After $2 \mathrm{~min}$, distilled water was added to obtain a final volume of $1.0 \mathrm{ml}$, and $100 \mu \mathrm{l}$ of it were injected into the HPLC column. $100 \mu \mathrm{l}$ of injected mixture contained 0.01 nmoles of D-Asp and 0.1 nmoles of each of the other amino acids.

\section{Statistical analyses}

Statistical analyses were performed using Statistical Package [11].

\section{Results}

To our knowledge, analysis of free amino acids in amphioxus tissues has never been carried out before. In the present study, using a sensitive HPLC method, we have determined the concentration of 19 free L-amino acids and D-aspartate in the central nervous system of amphioxus $B$. lanceolatum that mainly consists in an anterior brain vesicle and a neural tube (or spinal cord) (Fig. 1a, 1b, 1c). In order to detect fluorimetrically the concentration of each amino acid and of D-Asp, the dissected tissues were reacted with a mixture consisting of 0 phthaldialdehyde and N-acetylcysteine, and then injected into the HPLC column. Using this method we were able to obtain a clean separation of D-Asp from L-Asp as well as from other amino acid. Figure 2 shows a typical chromatographic example of a separation and quantification of each individual amino acid at HPLC from an extract of amphioxus neural tube (Fig. 2a), and a standard mixture of amino acids consisting of 19 different L-amino acids and DAsp (Fig. 2b). In Table 1 the composition of each amino acid (expressed in $\mu \mathrm{mol} / \mathrm{g}$ tissue \pm standard deviation) found in amphioxus nervous system is reported, and it is compared to that found in the brain of the cephalopod Octopus vulgaris [12], taken as representative of mollusc phyla, and of human brain as representative of mammals $[13,14]$.

As shown in Table 1, in amphioxus nervous system five free amino acids occur at relative concentrations between 1.10 and $4.50 \mu \mathrm{mol} / \mathrm{g}$ of tissue, whereas all other amino acids are between 0.11 to $0.45 \mu \mathrm{mol} / \mathrm{g}$ of tissue. However, among the higher concentrated amino acids, L-glutamic acid is the compound at highest concentration with $4.50 \pm 0.60$ $\mu \mathrm{mol} / \mathrm{g}$ of tissue followed by L-aspartic acid (3.90 \pm $0.30)$, L-alanine $(2.50 \pm 0.40)$, L-glycine $(2.35 \pm 0.35)$, and L-serine (1.10 \pm 0.25$)$ (Fig. 2a and Table1).
Table 1. Major free L-amino acids and D-aspartate in the nervous system of the Amphioxus. Results are expressed in $\mu \mathrm{mol} / \mathrm{g}$ tissue (mean $\pm \mathrm{SD}$ ). ${ }^{\mathrm{a}}$ from ref. [12]; ${ }^{\mathrm{b}}$ present work; ${ }^{\mathrm{c}}$ from ref. [13]; ${ }^{\mathrm{d}}$ from ref. [14]. For more details, see in the text.

\begin{tabular}{lccc}
\hline & $\begin{array}{c}\text { Mollusk } \\
\text { (O. vulgaris) }\end{array}$ & $\begin{array}{c}\text { Amphioxus } \\
\text { (B. lanceolatum) }\end{array}$ & $\begin{array}{c}\text { Mammalian } \\
\text { (H. sapiens) }\end{array}$ \\
L-Amino acids & Brain $^{\mathrm{a}}$ & Neural tube & Hippocampus \\
\hline Glutamate & $16.20 \pm 2.10$ & $4.50 \pm 0.60$ & $6.66 \pm 0.35$ \\
Glutamine & $2.80 \pm 0.40$ & $0.42 \pm 0.05$ & $3.80 \pm 0.40$ \\
Aspartate & $9.00 \pm 1.10$ & $3.90 \pm 0.30$ & $1.44 \pm 0.18$ \\
Asparagine & $0.92 \pm 0.20$ & $0.20 \pm 0.03$ & $0.18 \pm 0.02$ \\
Taurine & $80.20 \pm 7.10$ & $0.35 \pm 0.05$ & $1.87 \pm 0.24$ \\
Glycine & $2.40 \pm 0.30$ & $2.35 \pm 0.35$ & $1.68 \pm 0.17$ \\
GABA & $6.10 \pm 1.10$ & $0.27 \pm 0.04$ & $1.15 \pm 0.20$ \\
Alanine & $15.30 \pm 2.50$ & $2.50 \pm 0.40$ & $1.62 \pm 0.11$ \\
Serine & $1.50 \pm 0.30$ & $1.10 \pm 0.15$ & $0.86 \pm 0.08$ \\
Threonine & $1.30 \pm 0.20$ & $0.25 \pm 0.05$ & $0.42 \pm 0.06$ \\
Histidine & $2.60 \pm 0.70$ & $0.30 \pm 0.02$ & $0.41 \pm 0.06$ \\
Valine & $1.00 \pm 0.30$ & $0.11 \pm 0.03$ & $0.40 \pm 0.06$ \\
Arginine & $2.80 \pm 0.70$ & $0.38 \pm 0.05$ & $0.33 \pm 0.07$ \\
Tyrosine & $0.50 \pm 0.20$ & $0.15 \pm 0.02$ & $0.26 \pm 0.03$ \\
Methionine & $0.20 \pm 0.10$ & $0.22 \pm 0.03$ & $0.20 \pm 0.04$ \\
Isoleucine & $0.60 \pm 0.20$ & $0.23 \pm 0.02$ & $0.31 \pm 0.05$ \\
Leucine & $0.70 \pm 0.20$ & $0.30 \pm 0.15$ & $0.68 \pm 0.12$ \\
Phenylalanine & $0.04 \pm 0.01$ & $0.23 \pm 0.03$ & $0.34 \pm 0.05$ \\
Lysine & $0.40 \pm 0.10$ & $0.35 \pm 0.04$ & $0.44 \pm 0.07$ \\
& & & \\
\hline D-aspartate & $9.10 \pm 2.20$ & $0.28 \pm 0.04$ & $0.02 \pm 0.004 \mathrm{~d}$ \\
D/L-Asp & & & \\
Ratio $\%$ & $101 \%$ & $9.58 \%$ & $0.45 \%$ \\
& & &
\end{tabular}

As in molluscs and mammals, L-glutamic acid (and its amide derivative L-glutamine) and L-aspartic acid are present at high concentration in amphioxus neural samples compared to other free amino acids. These two compounds are well known to be excitatory amino acids and neurotransmitters of the nervous system. Thus, also in amphioxus these amino acids, since they are present at high concentration, are probably involved in neurotransmission. In molluscs, interestingly in addition to L-Glu and L-Asp other two amino acids are found at very high concentration: taurine and alanine, but their role in nervous system is still not completely understood.

Among other neuroactive substances, we found that the amino acid derivative GABA, the main inhibitory neurotransmitter of vertebrates, is present in low concentration compared to the other two animal's specie analyzed. About this topic a comprehensive study on GABAergic neuronal network in amphioxus have been carried out, demonstrating that GABA is a widely used neurotransmitter in both its central and peripheral nervous system [15]. 
Figure 2. (A) HPLC separation of L-amino acids and of D-Asp from amphioxus nervous system. The area of the peaks corresponds to amino acid concentrations coming from $0.1 \mathrm{mg}$ of tissue. (B) HPLC separation of a standard amino acids mixture containing 10 pmoles of D-Asp and 100 pmoles of L-amino acids.

A

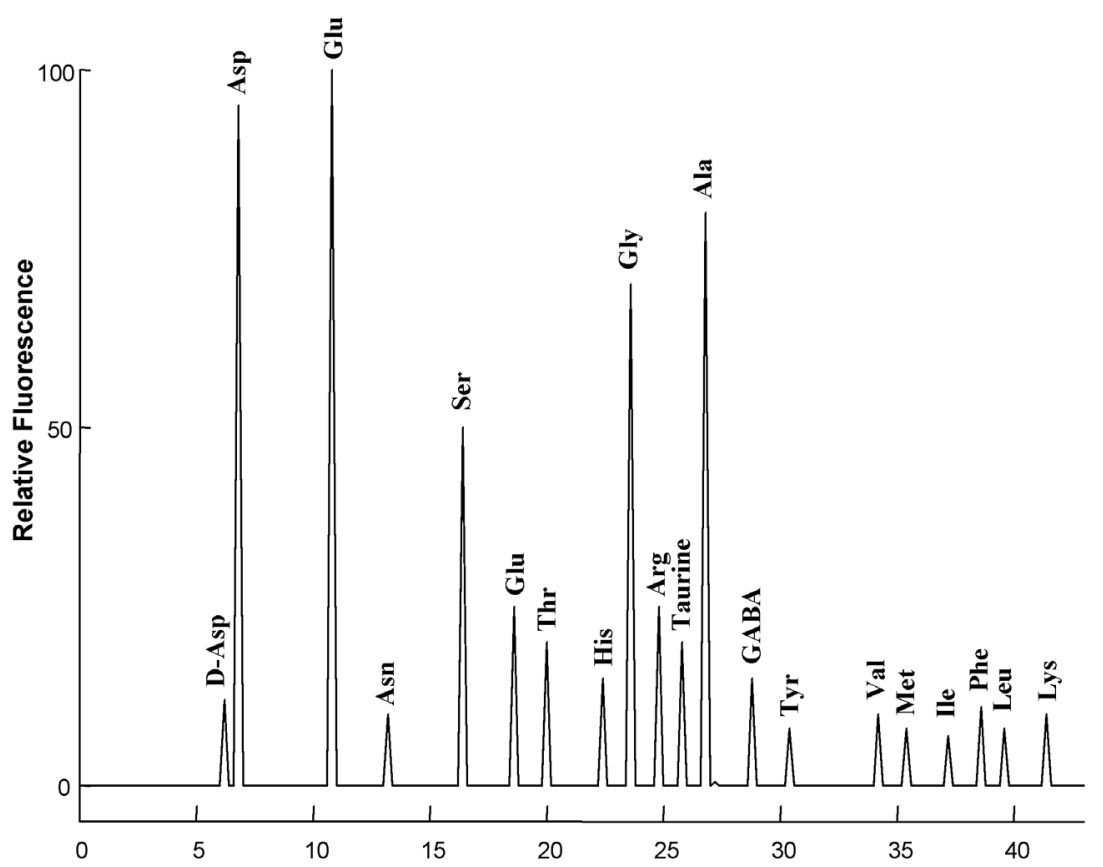

B

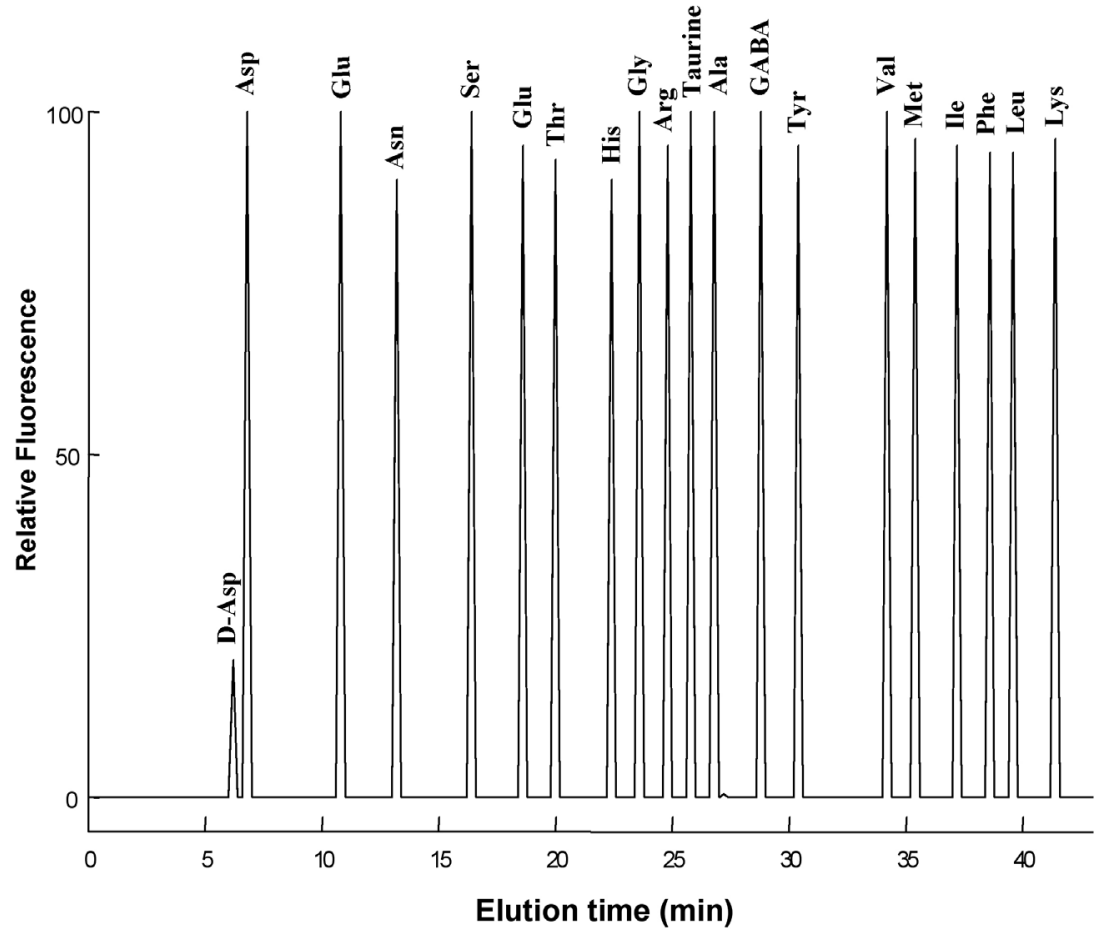




\section{Discussion}

The results obtained in the present study mimic the evolution of the nervous system from invertebrates to vertebrates. In fact, in molluscs and in mammals L-aspartic acid and especially L-glutamic acid are always found at the highest concentration in the nervous system compared to other amino acids. Our data confirm this statement since also in cephalochordates, which from an evolutionistic point of view are between molluscs and mammals, we found high value of these two excitatory amino acids.

In addition, as shown in Table 1, the nervous system of the mollusc $O$. vulgaris possess other two non-excitatory neutral amino acids: taurine and alanine. They are know to be involved in nervous system as neuroinhibitory transmitter, but considering its extremely abundance in molluscs brain it is supposed that they are needed for specific functions in molluscs, since neither the amphioxus nor mammals possess such high concentrations of these two compounds.

The present study thus strongly suggests that there is a relationship between the evolution of the nervous systems and its composition in free amino acids. The cephalochordates are phylogenetically closer to mammals than molluscs and this largely agree with our biochemical analysis. Still, it is unresolved why amphioxus and mammals, conversely to molluscs, do not possess such a high quantity of taurine and alanine.

Another interesting data regards the occurrence of D-aspartic acid in the nervous system of the amphioxus. In fact, as shown in Table 1, this amino acid is present in amphioxus neural tube at a very high concentration (considering the $\mathrm{D} / \mathrm{L}$ ratio percentage), as well as in molluscs, while it is present at relatively low concentration in mammals (Table 1 ), and in another animal phyla [9, 16, 17]. It has been demonstrated that during the last embryonic life in rat and chicken a transient increase of D-Asp occurs in the brain (200-300 nmol/g tissues) and then it returns to lower levels $(20-30 \mathrm{nmol} / \mathrm{g})$, and remains at that concentration for the rest of the life span of the animal $[18,19]$.

In addition, it has been also shown that D-Asp is involved in the function of the endocrine system, where it is capable to induce the release of hypothalamic GnRH (gonadotropin releasing hormone), pituitary hormones (LH, luteinizing hormone and $\mathrm{GH}$, growth hormone) [7] and testosterone [20]. Recently, D-Asp has also been found in the nervous ganglia of the opistobranchia Aplysia limacina, where it plays an active role in neurotransmission processes [8].

All the above data thus lead us to hypothesize that in amphioxus D-aspartic acid may also have a "neuroendocrine" role. It is most likely that the concentration of D-Asp $(0.28 \pm 0.04 \mu \mathrm{mol} / \mathrm{g}$ tissue $)$ and of other amino acids reflects in a way the evolution of the nervous system under a biochemical point of view since their amount in amphioxus has been found at concentration between that of molluscs (invertebrate) and mammals (vertebrate).

\section{Acknowledgements}

The authors are very grateful to Antimo D'Aniello for critical reading of the manuscript. This research was funded by grant BFU2005-00252 (Spanish Ministry of Science and Technology) and by the European Community's Human Potential Programme HPRN-CT-2002-00263/BMC 'Neurogenome'. S.D'A was supported by a postdoctoral contract from the above EC programme. J.P.A. holds a University of Barcelona predoctoral fellowship.

\section{Conflict of interest} exists.

The authors have declared no conflict of interest

\section{References}

1. Pallas PS. Spicilegia zoologica, quibus novae imprimus et obscurae animalium species iconibus, descriptionibus atque comentariis illustrantur. Berlin: GA Lange. 1774.

2. Costa OG. Cenni zoologici, ossia descrizione delle specie nuove di animali discoperti in diverse coutrade del regno nell'anno 1834. Annuario Zoologico 1834; 12:49.

3. Yarrell W. A history of British fishes. London: J Van Voorst. 1836.

4. Ruppert EE. Cephalochodata (Acraniata). In: Harrison FW and Ruppert EE editors. Microscopic Anatomy of Invertebrates. New York: Wiley-Liss. 1997: 349-504.

5. Kachmar JF, Grant GH, Bath FRG. Chemistry of amino acids and proteins. In: Tietz NW Ed. Fundamentals of Clinical Chemistry. WB Saunders Company. 1976: 264-271.

6. Danbolt NC. Glutamate uptake. Progress in Neurobiology 2001; 65:1-105.

7. D'Aniello A, Di Fiore MM, Fisher GH, Milone A, Seleni A, D'Aniello S, Perna A, Ingrosso D. Occurrence of D-Aspartic acid and N-methyl-D-aspartic acid in rat neuroendocrine tissues and their role in the modulation of luteinizing hormone and growth hormone release. FASEB J 2000; 14:699-714.

8. Spinelli P, Brown ER, Ferrandino G, Branno M, Montarolo PG, D'Aniello E, Rastogi PK, D'Aniello B, Baccari GC, Fisher G, D'Aniello A. D-aspartic acid in the nervous system of Aplysia limacina: Possible role in neurotransmission. J Cell Physiol 2006; 206(3):672-681.

9. D'Aniello S, Spinelli P, Ferrandino G, Peterson K, Tsesarskia M, Fisher GH, D'Aniello A. Cephalopod vision involves dicarboxylic amino acids: D-aspartate, L-aspartate and Lglutamate. Biochemical J 2005; 386:331-340.

10. Wang H, Wolosker H, Morris JF, Snyder SH, Selkoe DJ. Naturally occurrence free D-aspartate is a nuclear component of cells in the mammalian hypothalamus-neurohypophyseal system. Neuroscience 2002; 109(1): 1-4.

11. StatSoft. Statistical Package, 98th Edition. StatSoft. 1997.

12. D'Aniello A, Nardi G, De Santis A, Vetere A, Di Cosmo A, Marchelli R, Dossena A, Fisher G. Free L-amino acids and Daspartate contents in the nervous system of cephalopods. Comp Biochem Physiol 1995; 112B:661-666.

13. Tarbit EK, Perry RH, Blessed G, Tomlinson BE. Hippocampal free amino acids in Alzheimerr's Disease. J Neurochem 1980; 35:1246-1249.

14. Fisher GH, D’Aniello A, Vetere A, Padula L, Cusano G, Man EH. Free D-aspartate and D-alanine in normal and Alzheimer brain. Brain Res Bull 1991; 26:983-985. 
15. Anadón R, Adrio F, Rodríguez-Moldes I. Distribution of GABA immunoreactivity in the central and peripheral nervous system of Amphioxus (Branchiostoma lanceolatum Pallas). J Comp Neurol 1998; 401:293-307.

16. Hashimoto A, Oka T, Nishikawa T. Anatomical distribution and postnatal changes in endogenous free D-aspartate and Dserine in rat brain and periphery. European J Neurosc 1995; 7:1657-1663.

17. Hashimoto A, Nishikawa T, Oka T, Hayashi T, Takahashi K. Widespread distribution of free $\mathrm{D}$-aspartate in rat periphery. FEBS Letters 1993; 331:4-8.

18. Neidle A, Dunlop DS. Developmental changes of free Daspartic acid in the chicken embryo and in the neonatal rat. Life Science 1990; 46:1517-1522.

19. Dunlop DS, Neidle A, McHale D, Dunlop DM, Lajtha A. The presence of free D-Aspartic acid in rodents and man. Biochem Biophys Res Comm 1986; 142:27-32.

20. D'Aniello A, Di Cosmo A, Di Cristo C, Annunziato L, Petrucelli $\mathrm{L}$, Fisher GH. Involvement of D-aspartic acid in the synthesis of testosterone in rat testes. Life Science 1996; 59:97-104. 